\title{
ARQUITETURA DO ESPAÇO ESCOLAR, ADEQUAÇÃO DA EDIFICAÇÃO AOS PARÂMETROS AMBIENTAIS: ESTUDO DE CASO CTISM - COLÉGIO TÉCNICO INDUSTRIAL DE SANTA MARIA
}

http://dx.doi.org/10.5902/2176217114673

\author{
Madalena Russi \\ Universidade Federal de Santa Maria, Brasil. \\ Karla Marques da Rocha \\ Universidade Federal de Santa Maria, Brasil.
}

\begin{abstract}
Resumo
A constante busca por conforto térmico nas habitações tem como um impasse o crescente apelo pela redução do consumo da energia elétrica. O presente artigo trata das estratégias possíveis para o melhoramento do conforto ambiental térmico nos ambientes escolares. Para definir parâmetros de conforto térmico nas edificações escolares e evidenciar estratégias de condicionamento térmico, utilizamos os resultados do preenchimento das cartas bioclimáticas de Givoni e o método de Mahoney, consagrados estudiosos sobre a questão térmica em edificações em clima temperado. Escolheu-se o Colégio Técnico Industrial de Santa Maria - Ctism - para demonstrar as possibilidades que permeiam uma edificação existente. Como principais estratégias foram identificadas a adequação do tamanho e posição solar das esquadrias, com vistas à melhorar a ventilação interna da edificação e diminuir a carga solar recebida. Além disso, sugerese a utilização de cores claras nos fechamentos laterais e na cobertura para diminuir a carga térmica absorvida.
\end{abstract}

Palavras-chave: conforto térmico, cartas de Mahoney, método de Givoni, sustentabilidade.

\section{SCHOLAR SPACE'S ARCHITECTURE, ADEQUATION OF EDIFICATION ENVIRONMENTAL PARAMETERS: CASE STUDY OF CTISM - COLÉGIO TÉCNICO INDUSTRIAL DE SANTA MARIA}

\section{Abstract}

The constant search for thermal comfort in residences has one great barrier to overcome, the emerging plea of electrical energy consumption reduction. This paper discuss some strategies to improve thermal comfort in educational environments. To set parameters for thermal comfort in educational buildings and to point strategies for thermal conditioning we used the Givoni's bioclimatic charts results, through Mahoney`s method, they were experts in the field of thermal building in temperate climates. For demonstration, the Colégio Técnico Industrial de Santa Maria Ctism - was chosen as study case, in order to demonstrate the possibilities around a building. The main identified strategies were the adjustment of the position, size and the miter's solar position for 
the purpose of having better internal ventilation in the building and lower solar exposure. Furthermore, the use of bright colors in the sidewalls and roof in order to reduce the absorbed heat.

Key-words: thermal comfort, mahoney`s chart, givoni's method, sustainability. 


\section{Introdução}

$\mathrm{R}$

econhece-se o estudante como sujeito do processo escolar e como o principal usuário do ambiente escolar. Neste cenário é necessário identificar parâmetros essenciais de qualidade do ambiente físico que ofereça dependências adequadas à aprendizagem, proporcionem conforto ambiental aos usuários, bem como conforto térmico, visual, acústico, olfativo/qualidade do ar e qualidade sanitária dos ambientes. Essa qualidade ambiental deve ter relação harmoniosa da edificação com seu entorno e aliar conforto a sustentabilidade das edificações.

A adequação do espaço físico no ambiente escolar se relaciona com as diretrizes estabelecidas pelo Plano Nacional de Educação, que faz menção à promoção da sustentabilidade socioambiental.

Dessa forma, este estudo visa a uma análise acerca da adequação das edificações escolares aos parâmetros ambientais, tendo como foco o estudo do conforto térmico para edificações mais sustentáveis nas instituições escolares. Nesse sentido, foi feito um estudo de caso no Colégio Técnico Industrial de Santa Maria sobre as possibilidades de inserção, neste colégio, dos parâmetros de conforto ambiental térmico.

\section{Referencial teórico}

Nos últimos anos, os edifícios têm sido condicionados artificialmente por meio de aparelhos mecânicos e elétricos para aquecer, arrefecer, ventilar e iluminar. Com isso, a envoltória do edifício deixou de ser o principal moderador do clima exterior no ambiente interno e os projetistas passaram a abdicar da responsabilidade da climatização natural e da suficiência de energia. A crescente preocupação ambiental e energética tornou necessário buscar soluções alternativas para diminuir essa dependência.

Um projeto que usa estratégias passivas tira proveito das condições climáticas e dos recursos naturais do local, visando reduzir o consumo energético nas edificações e, por conseguinte, maximizar os benefícios térmicos e ambientais. As estratégias para um projeto passivo variam conforme o clima de cada região onde é aplicado mas, em geral, utilizam a forma da edificação, a disposição das aberturas e o desempenho térmico dos materiais.

\section{Estratégias bioclimáticas de conforto térmico}

A Bioclimatologia é a ciência que estuda a climatologia aplicada com relação aos seres vivos. A Bioclimatologia aplicada na arquitetura se baseia no correto uso dos elementos arquitetônicos, para obter conforto higrotérmico e pouco consumo energético.

Para aumentar a sensação de conforto, desde a metade do século passado diversos autores têm estudado estratégias bioclimáticas para projetos arquitetônicos. Os irmãos Olgyay (1963) foram os pioneiros em propor um procedimento sistemático para adaptar o projeto de uma edificação às condições climáticas. Posteriormente este método foi aperfeiçoado por Givoni (1992), que indicou adequadas soluções e estratégias para melhoramento do conforto térmico. 


\section{Bioclimatologia aplicada a zona bioclimática brasileira}

Segundo a norma NBR 15220-3 (ABNT, 2005), o Brasil é dividido em oito zonas bioclimáticas. Santa Maria, RS, está situada na zona 2, figura 1, caracterizada por estações climáticas bem definidas, com grande amplitude térmica ao longo do dia e mudanças bruscas de temperatura no decorrer do ano, devido a entrada sistemática de frentes frias oriundas do Sul do continente. Esta região possui grande complexidade na busca de estratégias para o conforto térmico, pois, as mesmas devem atender, tanto ao clima frio, quanto o clima quente, que ocorrem nesta região no decorrer do ano.

Em 1969 Givoni concebeu uma carta bioclimática para edifícios que corrigia algumas limitações do diagrama idealizado por Olgyay. A carta de Givoni se baseia em temperaturas internas do edifício, propondo estratégias construtivas para a adequação da arquitetura ao clima. No Brasil temos publicadas as cartas bioclimáticas de todas as capitais. Observando-se a carta da figura 2 , se verifica a grande variação climática da cidade de Porto Alegre ao longo do ano. A mancha alongada, constituída por pontos vermelhos que representam cada hora do ano, percorre desde a região onde é indicado 0 aquecimento artificial até o início da zona de ar condicionado. Tem-se que em $22,4 \%$ das horas do ano haverá conforto térmico e em $77,5 \%$ o desconforto, este desconforto se divide em $22,9 \%$ provocado pelo calor e $51,6 \%$ pelo frio.

Figura 1 - Mapa Zonas bioclimáticas (ABNT, 1998).

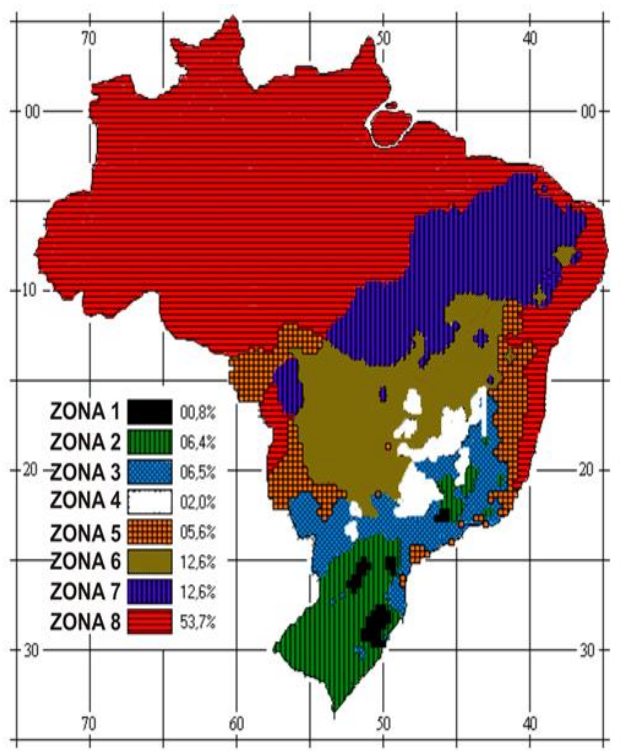

Figura 2 - Carta bioclimática (Lamberts, 1997).

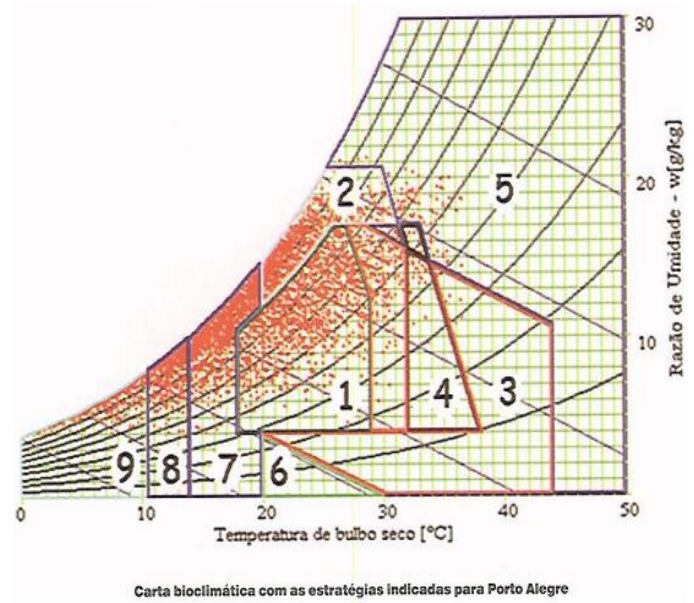

Paralelo às cartas bioclimáticas temos o método de Mahoney, outro balizador nas estratégias de projeto bioclimático. Mahoney desenvolveu tabelas que são preenchidas com as informações climáticas locais e resultam num indicativo de orientação solar, formato e estrutura, necessários ao estágio inicial de projeto. Possui como vantagem o 
fato de não necessitar de hipóteses preliminares, sendo necessária apenas a comparação entre as tabelas preenchidas com os dados coletados do clima e o conforto limite aconselhado para cada local.

\section{Estratégias bioclimáticas para a região de Santa Maria Posicionamento solar da edificação}

Para traçar os diagramas solares considera-se a Terra fixa e o Sol percorrendo a trajetória diária da abóbada celeste, variando de caminho em função da época do ano, conforme mostra figura 3. Nela, veem-se os limites da trajetória anual que consistem nosso solstício de inverno de verão, enquanto alinha do meio indica o equinócio.

O correto posicionamento solar das edificações é de fundamental importância quando tratamos de estratégias sustentáveis para o conforto térmico dos indivíduos. A Figura 3 retrata uma edificação situada no hemisfério Sul e pode-se perceber que a face com maior exposição solar é a face Norte. Também é possível verificar que a fachada Sul não recebe nenhuma insolação, além disso, a fachada situada ao Leste recebe insolação matinal enquanto sua oposta recebe forte insolação no final da tarde.

Figura 3 - Trajetória anual, solstício de inverno de verão (Lamberts et. al., 1997).

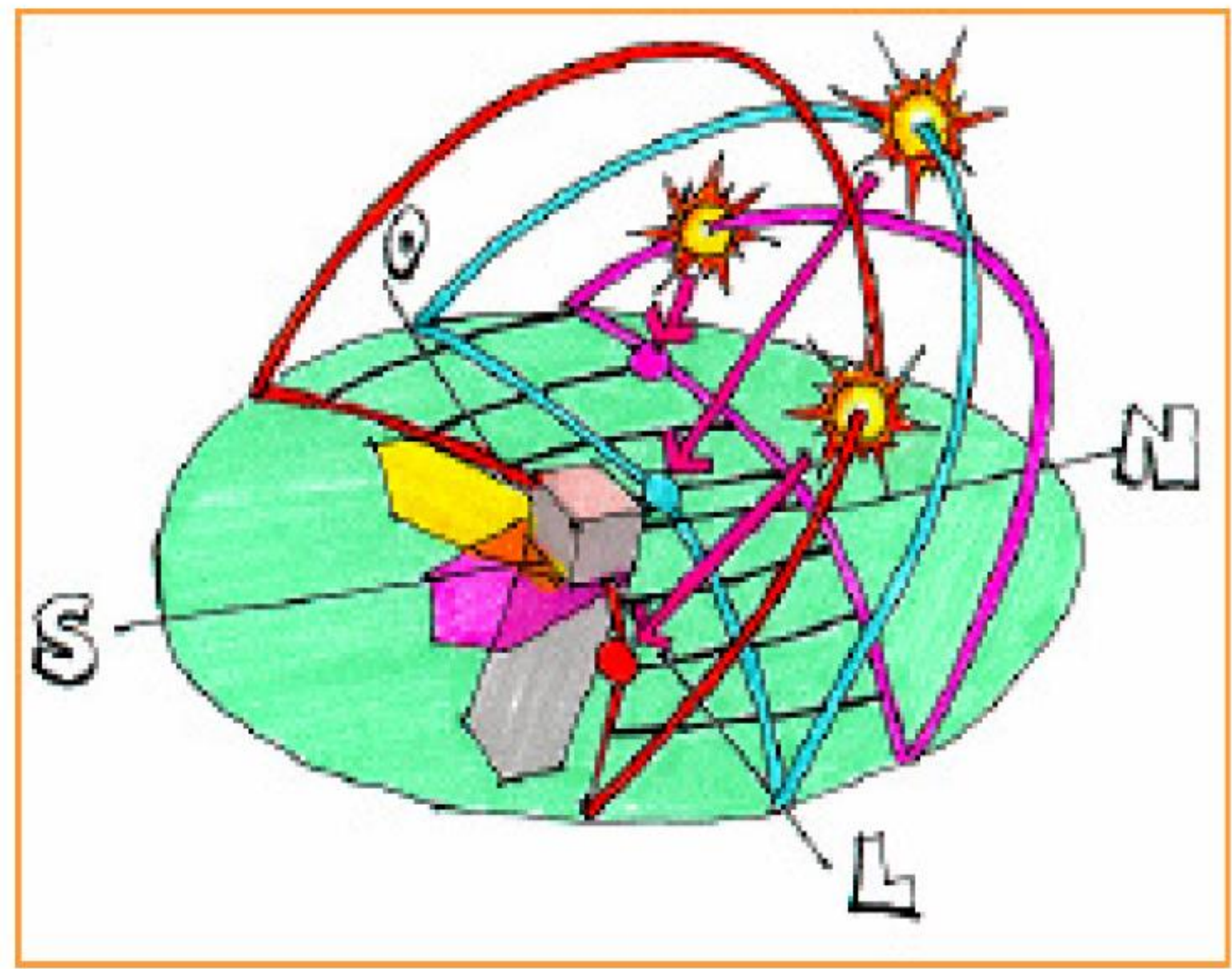

Considerando o clima subtropical úmido da cidade de Santa Maria, têm-se como fachadas privilegiadas pela insolação as posições solares Leste e Norte. A posição Leste, 
sol da manhã, favorece uma insolação com pouca intensidade e por um período bastante curto.

A insolação da fachada Norte apresenta uma peculiaridade bastante especial, pois durante os meses de verão não recebe o sol diretamente e nos meses de inverno, pelo deslocamento do eixo da Terra, recebe a incidência dos raios solares. Sendo esses os meses mais frios, nos quais a incidência da radiação solar é desejável, isso torna esse posicionamento solar o mais nobre para o clima no qual se encontra a cidade de Santa Maria, pois no período de calor não recebe insolação e no período de frio recebe a radiação direta, o que é muito conveniente.

\section{Efeito estufa}

O principal problema nos períodos quentes é controlar, na radiação solar, as parcelas que são transmitidas diretamente e reemitida para o interior pelos fechamentos transparentes, figura 4 (Lamberts, 1997). Em climas frios, acontece exatamente o contrário, figura 5 , os vidros devem ser posicionados na edificação para absorver a maior quantidade possível de energia térmica.

Figura 4 - Efeito estufa (Lamberts et. al., Figura 5 - Efeito estufa no inverno. 1997).
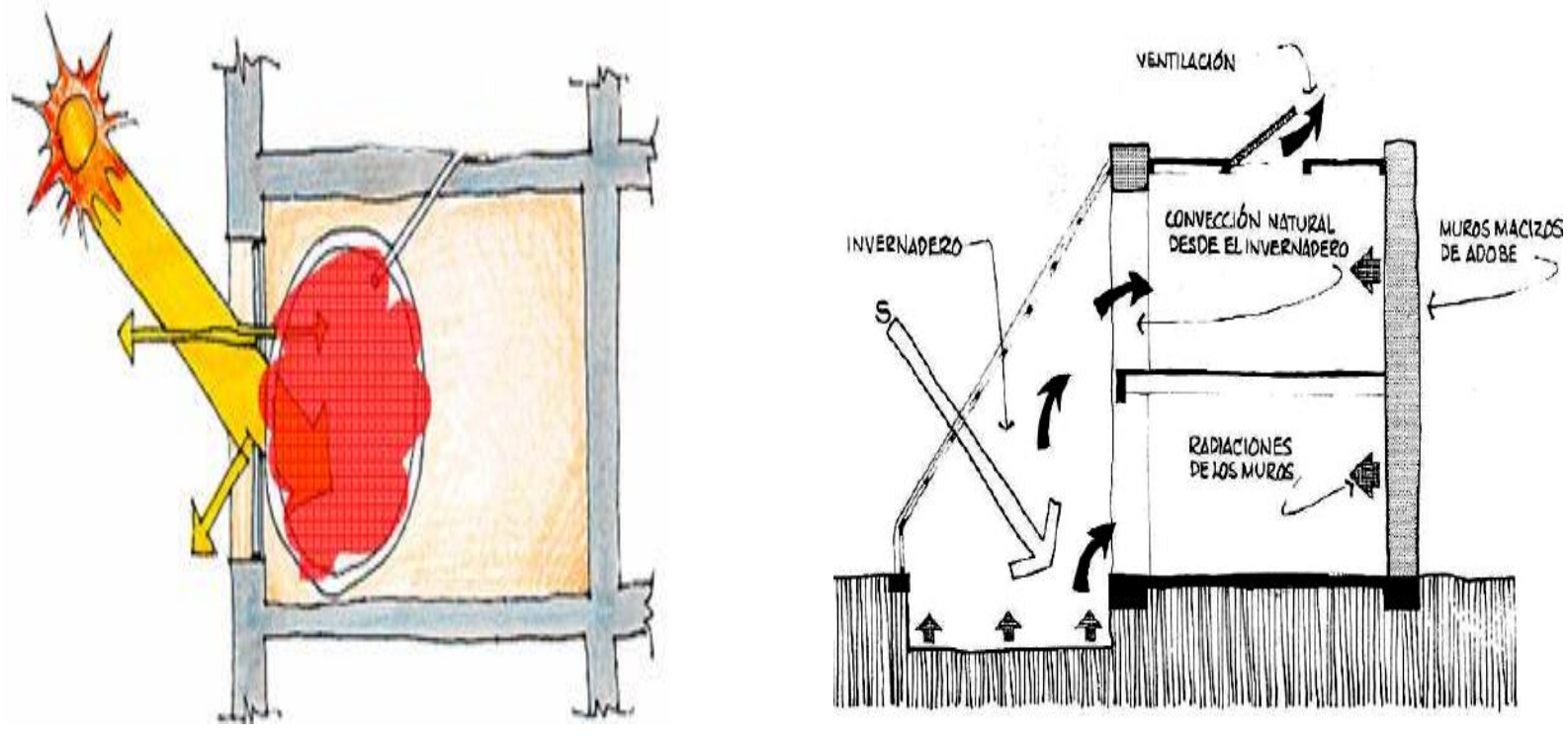

O sol emite radiações em todos os comprimentos de onda, mas a maior parte está dentro da faixa da luz visível (de 380 a $750 \mathrm{~nm}$ ). Quando essa radiação passa pelo vidro, parte dessa energia é absorvida pelos materiais no interior do ambiente, parte é refletida e parte é absorvida pelo vidro e se divide: uma parte para o interior da edificação e outra parte é perdida para o exterior. 
Essa energia refletida é a radiação infravermelha (de 4 a $40 \mu \mathrm{m}$ ) que, por ter um grande comprimento de onda, não passa pelo vidro, ficando aprisionada. Sendo assim, há um armazenamento de energia térmica dentro da edificação, provocando um aumento na temperatura, pois nem toda a energia que entrou sairá.

Figura 6 - Fator solar dos vidros (Lamberts et. al., 1997).

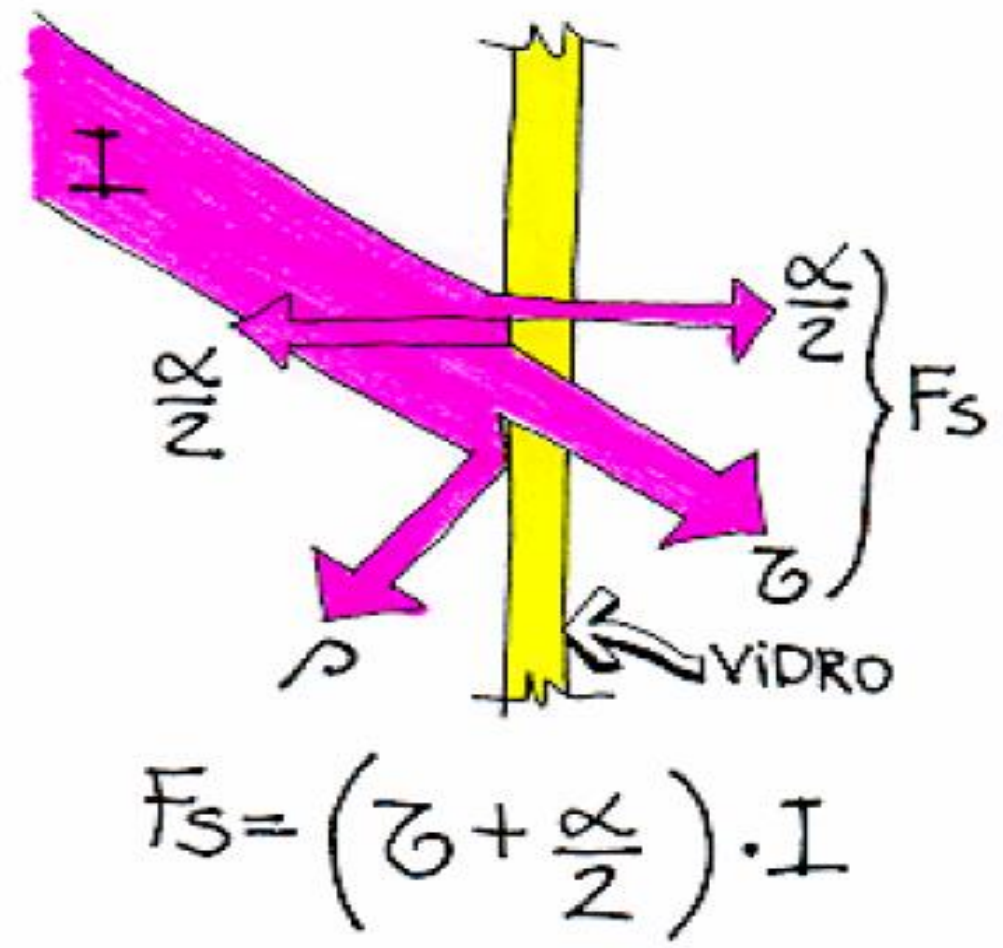

A quantidade de energia que passa pelo vidro depende do fator solar específico de cada vidro. Fator solar, como exemplifica a figura 6, é a razão entre o fluxo de calor solar, que penetra através da abertura, e o valor da radiação solar incidente no vidro.

\section{Ventilação cruzada e ventilação por diferença de pressão}

A ventilação cruzada é uma das estratégias bioclimáticas mais importantes, pois através dela é controlada a temperatura, a umidade do ar e a higienização nos ambientes. A ventilação natural é o fenômeno da movimentação do ar no interior das edificações sem a indução de nenhum sistema mecânico. Segundo Toledo (1999) ocorre por diferença de pressão do ar, que pode ocorrer por ação dos ventos ou diferença de densidade do ar devido à diferença de temperatura. Em ambos os processos é obrigatória a existência de aberturas para que $o$ ar possa fluir pelo edifício.

São as diferenças entre as temperaturas do ar interior e do ar exterior que provocam um deslocamento da massa de ar da zona de maior para a de menor pressão. Como exemplificam as figuras 7 e 8 , deve haver mais de uma abertura em cada ambiente e elas devem estar em paredes opostas para que haja fluxo de ar. 
Figura 7 - Ventilação cruzada.
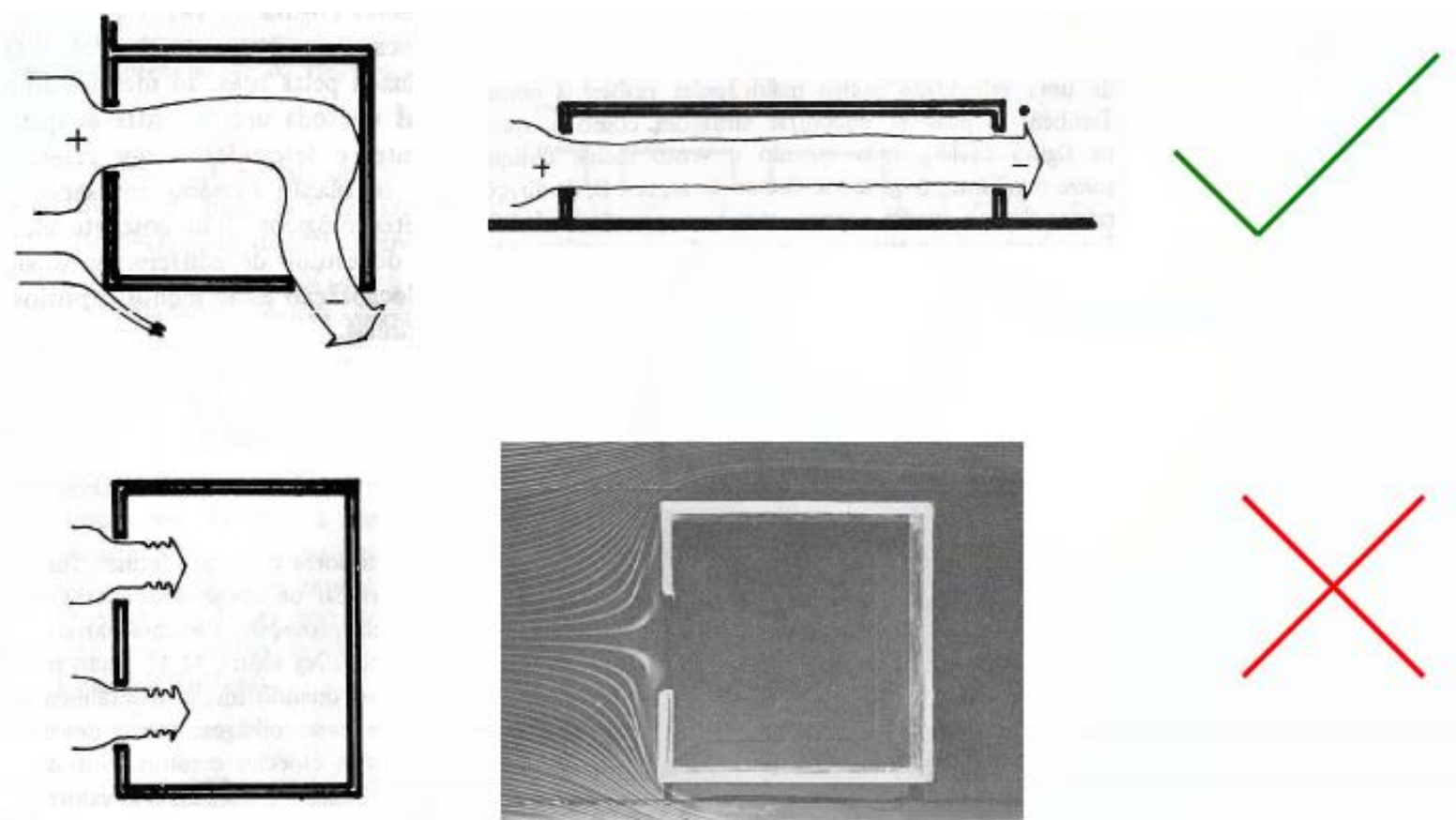

Figura 8 - Trajeto da ventilação cruzada.

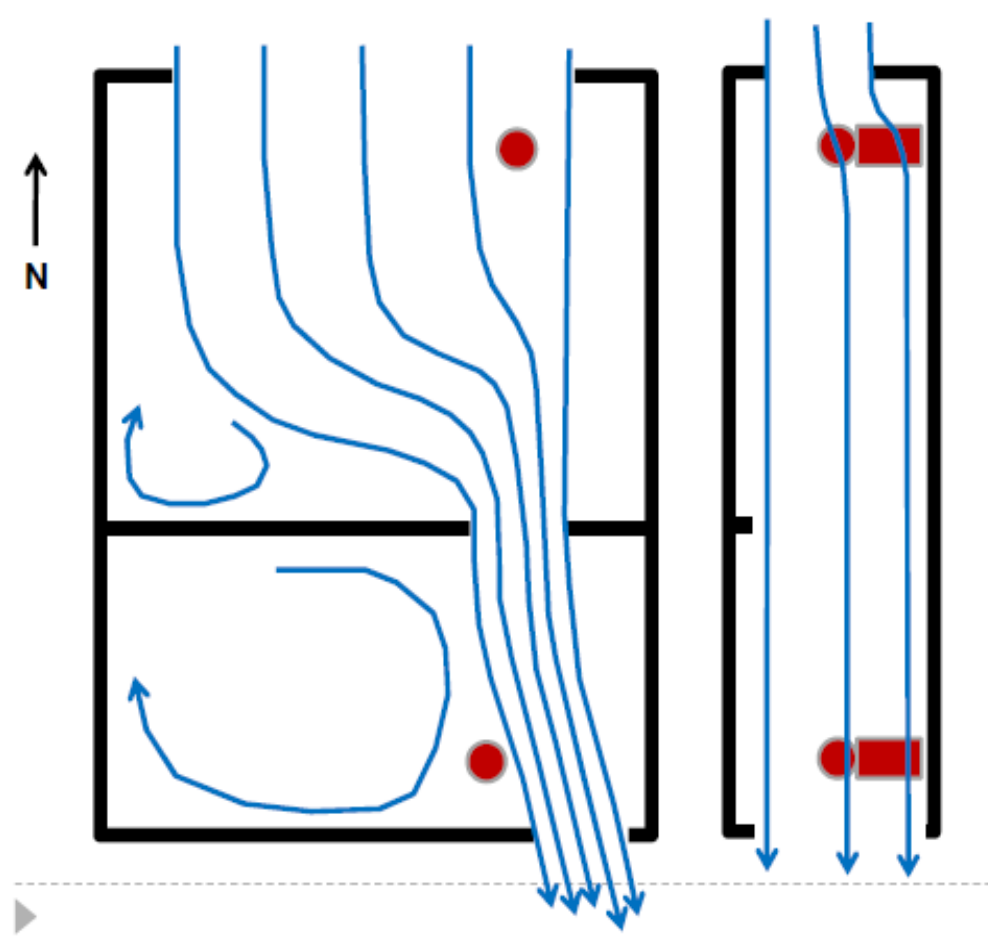

Quando as aberturas para a ventilação cruzada estão em diferentes alturas, temos a ventilação por diferença de pressão, essa diferença de altura maximiza o efeito da ventilação, pois o ar o ar quente, menos denso, tende a subir e encontrando uma abertura 
próximo ao teto cria uma corrente de vento ascendente dentro da edificação, como mostra a figura 9.

Figura 9 - Ventilação por diferença de pressão, por meio de uma esquadria (Lengen, 2008).

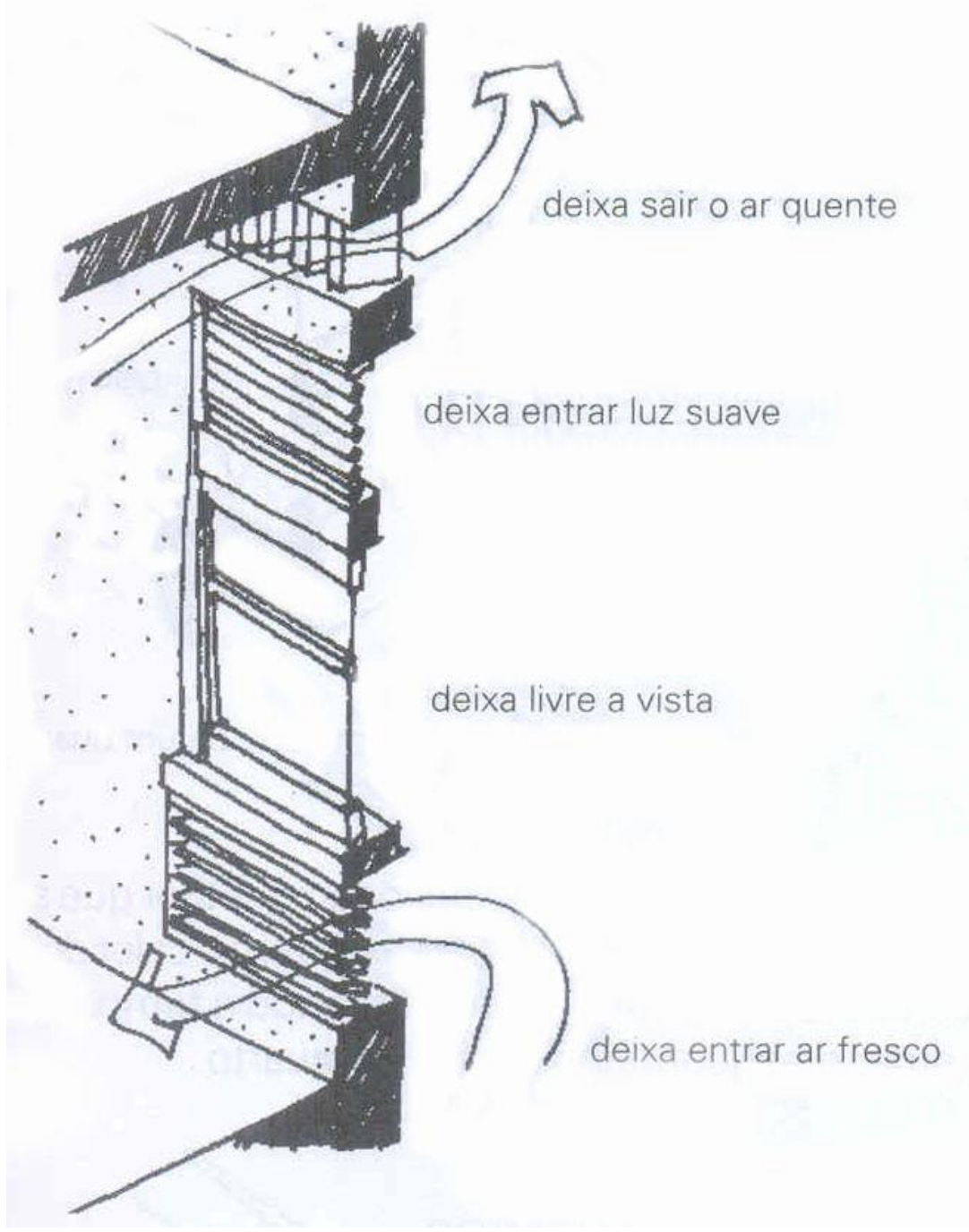

A ventilação pode ser maximizada quando se tira proveito da diferença de pressão entre as aberturas de entrada e saída do ar, pelas variações de pressão devido ao distanciamento vertical entre elas. Este processo também é conhecido como efeito chaminé. Quanto maior a variação e altura da entrada para a saída de ar, melhor o funcionamento dessa estratégia. 
Figura 10 - Exemplificação do efeito chaminé.
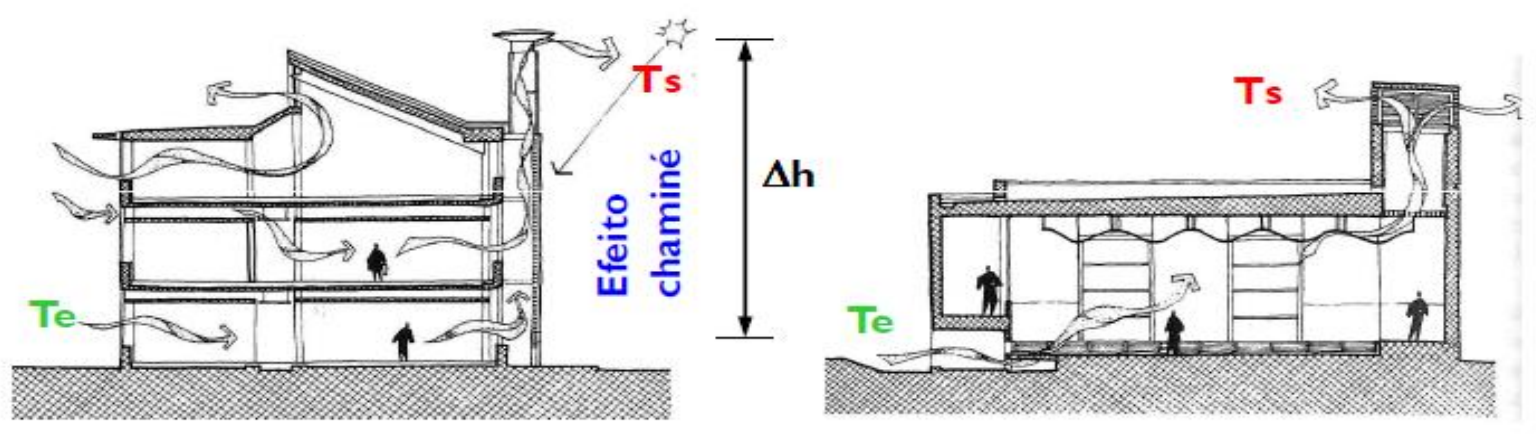

> Vazão quanto $\left\{\begin{array}{l}\gg>\Delta h \\ \gg \Delta T\end{array}\right.$

$\mathrm{Na}$ figura 10 vemos uma estratégia que maximiza a ventilação por diferença de pressão, são as torres de vento, nas quais a entrada de ventilação tem uma ligação subterrânea e a saía acima da altura do telhado.

Durante o período de inverno, no qual a ventilação no nível dos ocupantes não é desejável, deve ser mantida uma ventilação de baixa intensidade e esta não deve passar pelo nível dos ocupantes. Para a higienização dos ambientes, ela pode ser feita como mostra a figura 11.

Figura 11 - Ventilação verão inverno.

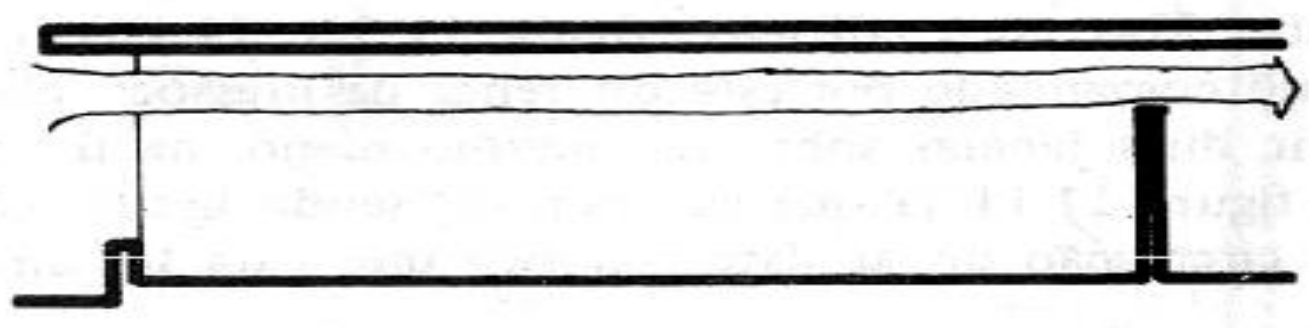

INVERNO

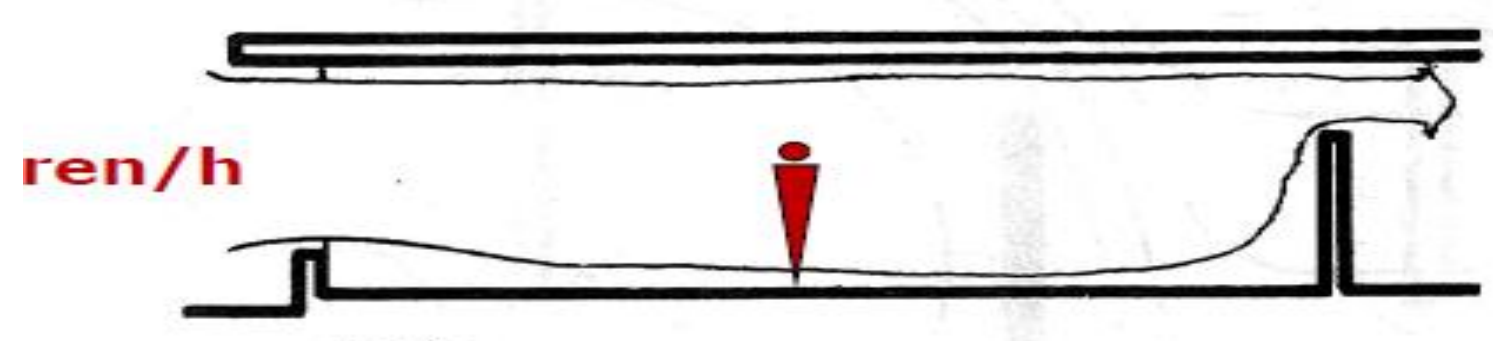

VERÃO 
Quando o vento passa no nível dos ocupantes, ele desloca o ar junto a pele de cada indivíduo, causando a sensação de diminuição da temperatura, o que é desejável nos períodos quentes.

\section{Sombreamento por brises e por vegetação}

O uso de vegetação para proteger fachadas com grande insolação é uma estratégia bastante usual nos climas quentes. É importante impedir a entrada direta dos raios solares no interior da edificação para evitar o efeito estufa. Para o clima subtropical, o uso de plantas caducifólias pode ser uma solução para os diferentes climas do ano, (Lamberts, 1997), como se vê na figura 12. Durante o período quente a vegetação sombreia a janela sem bloquear a luz natural e durante o período frio, no qual as folhas das árvores caem, permite a desejável incidência solar no edifício. Uma boa exemplificação do uso de vegetação para proteger edificações da irradiação solar é a figura 13.

Figura 12 - Uso da vegetação clima subtropical (Lamberts et. al., 1997).

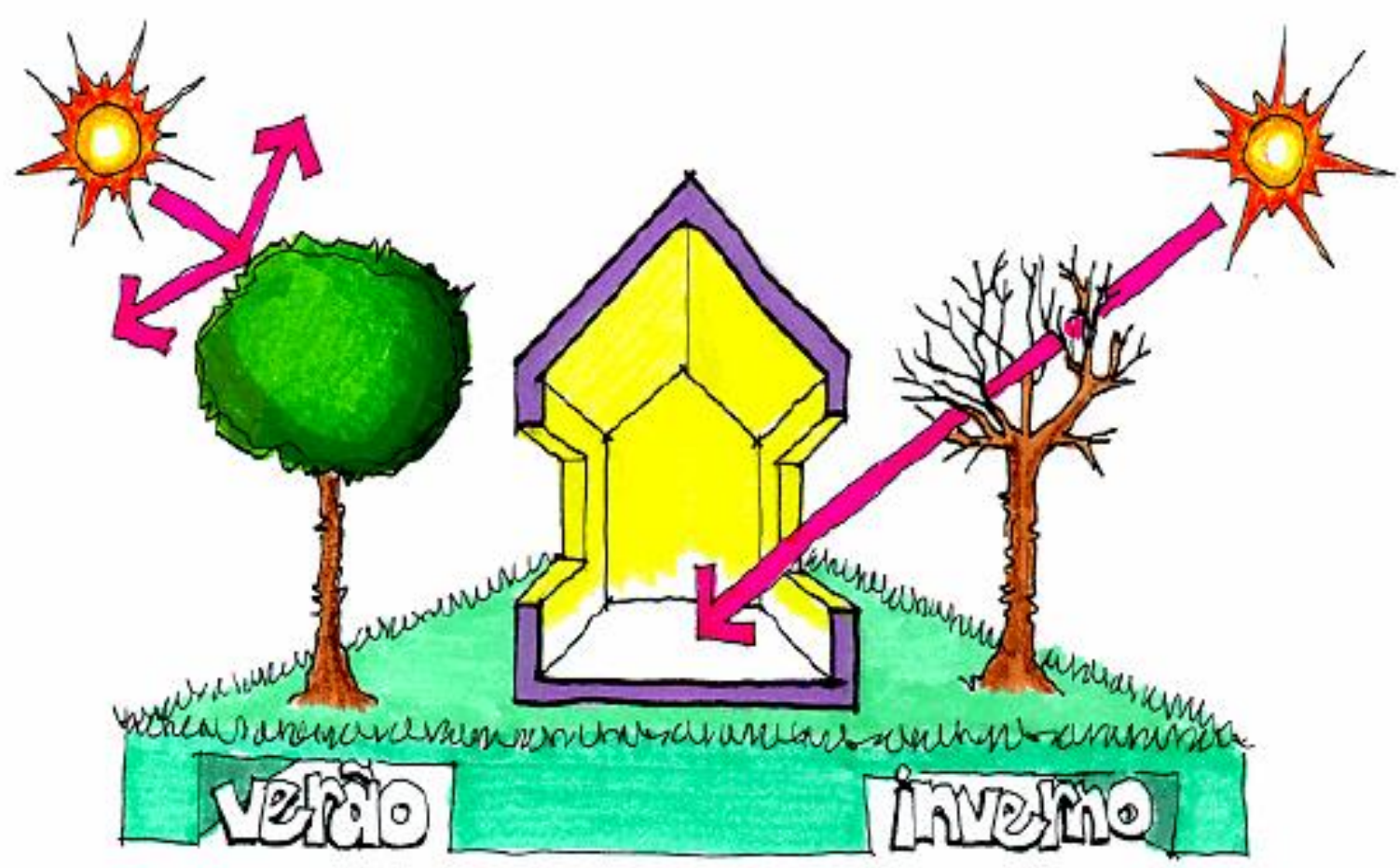


Figura 13 - Uso da vegetação para proteger a edificação da insolação.

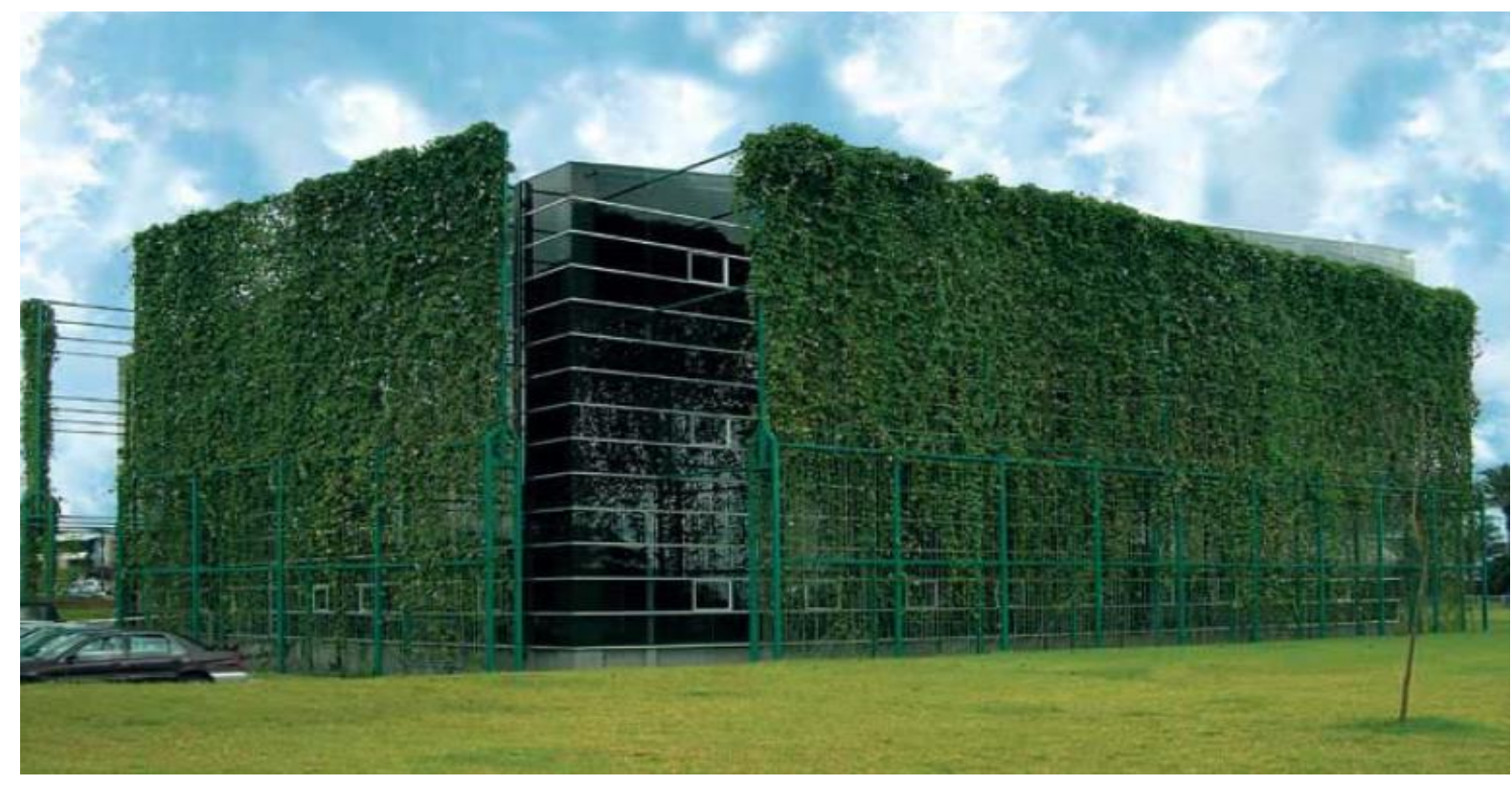

Uma boa forma de proteger esquadrias voltadas para o Oeste é com o uso do brisesoleil, expressão francesa cuja tradução significa quebra-sol. O uso dos brises se popularizou mundialmente com a arquitetura moderna e podem ser de diversos materiais, fixos ou móveis. São usados principalmente na fachada Oeste para proteger a edificação e fazer sombra nas áreas mais sensíveis com fechamento em vidro.

\section{Metodologia}

A metodologia utilizada foi um estudo de caso, que se caracteriza pela abordagem aprofundada de um ou de poucos objetos, de maneira que permita seu amplo e detalhado conhecimento. Pode ser definido como um conjunto de dados que descrevem uma fase ou a totalidade do processo social de uma unidade, em suas diversas fixações culturais e em suas relações internas.

As principais vantagens do estudo de caso são o estímulo a novas descobertas, a ênfase na totalidade e a simplicidade dos procedimentos. Há algumas limitações nesse estudo, sendo considerada mais grave a dificuldade de generalização dos resultados obtidos.

\section{Estudo e aplicação dos conceitos de conforto térmico no Ctism}

Definindo os parâmetros de conforto térmico para edificações educacionais para a região central do Rio Grande do Sul

A região central do Rio Grande do Sul possui um clima caracterizado pelos períodos frios que se alternam com os quentes, ao longo do dia e do ano, levando a necessidade do projeto arquitetônico apresentar estratégias de condicionamento térmico diferenciadas para esses períodos. Além da temperatura, outra variável importante nesse clima é alta umidade do ar. 
Para definir parâmetros de conforto térmico nas edificações escolares e evidenciar estratégias de condicionamento térmico, utilizamos os resultados do preenchimento das cartas bioclimáticas de Givoni do método de Mahoney.

Como preenchimento das Cartas de Givoni obtém-se como resultado para esta região quatro principais estratégias: o uso de massa térmica para aquecimento com aquecimento solar passivo (33,7\%); ventilação (19,5\%); aquecimento solar passivo (11,7\%); aquecimento artificial (6\%) (Lamberts, 1997).

Pelo Método de Mahoney obtemos como recomendando para o clima dessa região: implantação de edifícios alongados, com fachadas maiores voltadas para Norte e Sul; espaços entre as edificações para melhorar a ventilação, com possibilidade de controle; disposição das edificações em filas simples ao longo do edifício para obter ventilação cruzada permanente; utilização das aberturas do tamanho de 25 a $40 \%$ das fachadas Norte e Sul e/ou Leste e Oeste, quando o período frio for predominante; dispersão radiação solar direta nos interiores da edificação; posicionamento das aberturas nas fachadas Norte e Sul, permitindo ventilação ao nível dos corpos dos ocupantes; utilização d pisos e paredes leves e refletoras, assim como coberturas leves e isolantes.

\section{Caracterizando a edificação escolhida para o estudo de caso: Ctism}

O Colégio Técnico Industrial de Santa Maria situa-se no terreno da Universidade Federal de Santa Maria. Em seu entorno se destaca a grande quantidade de vegetação de grande porte. As figuras 14 e 15 mostram o entorno a edificação bastante arborizado.

Figura 14 - Vista aérea da edificação (www.googlemaps.com).

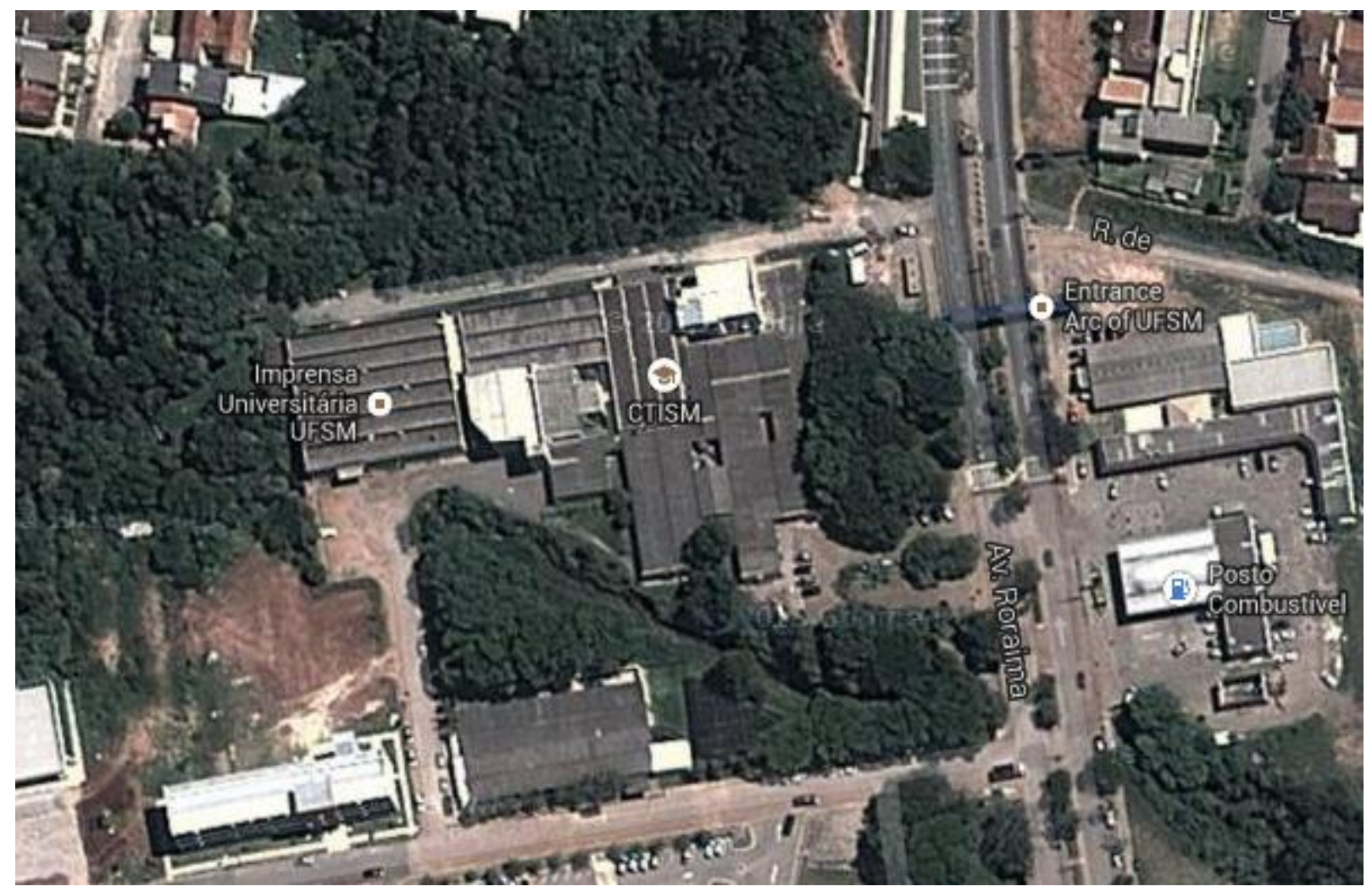


Foto 15 - Edificação do Ctism.

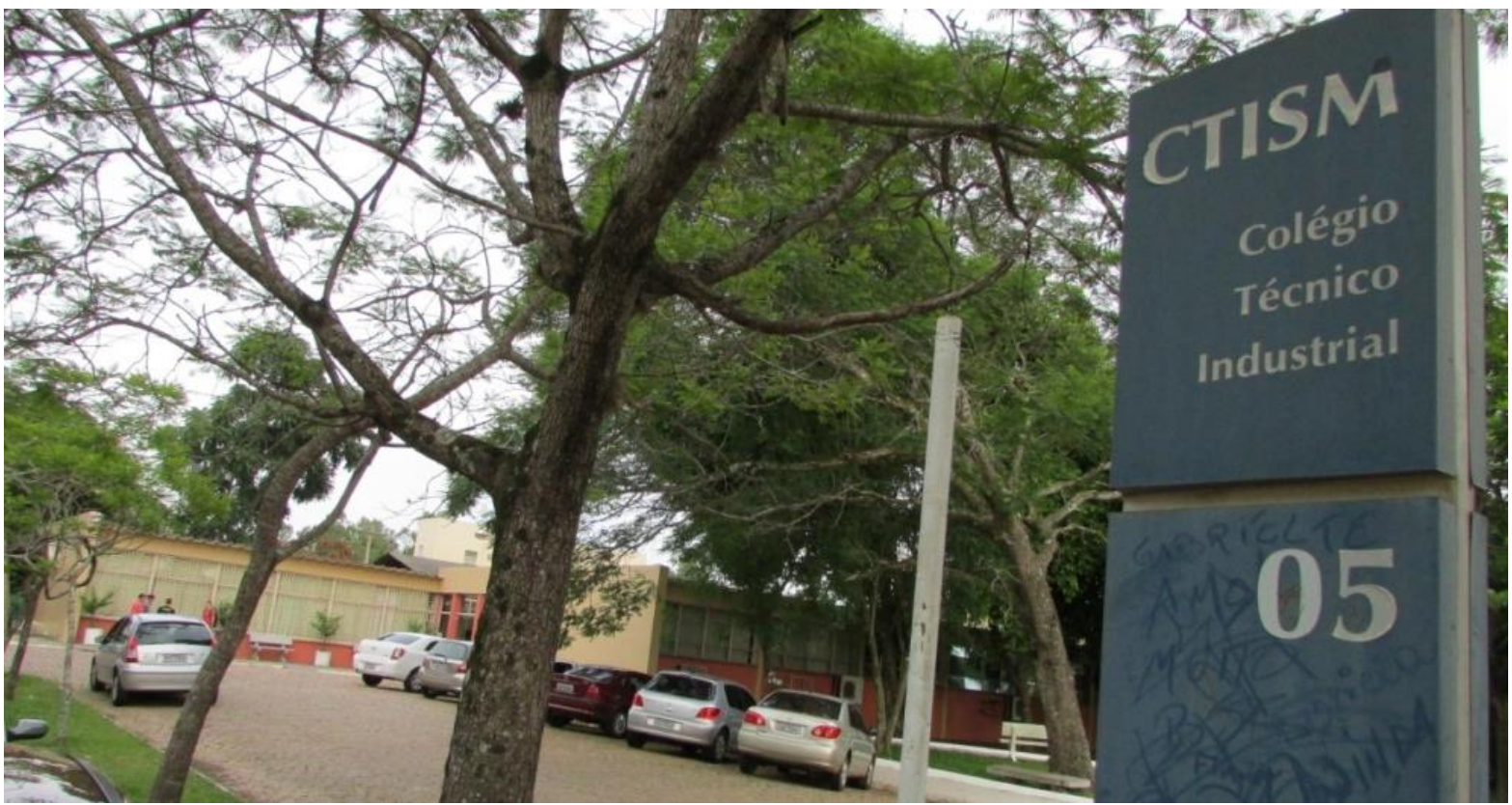

O Colégio é, na sua maior parte, condicionado artificialmente com aparelhos de ar condicionado, conforme podemos observar imagens que seguem.

Figura 16 - Salas do Ctism condicionadas artificialmente.

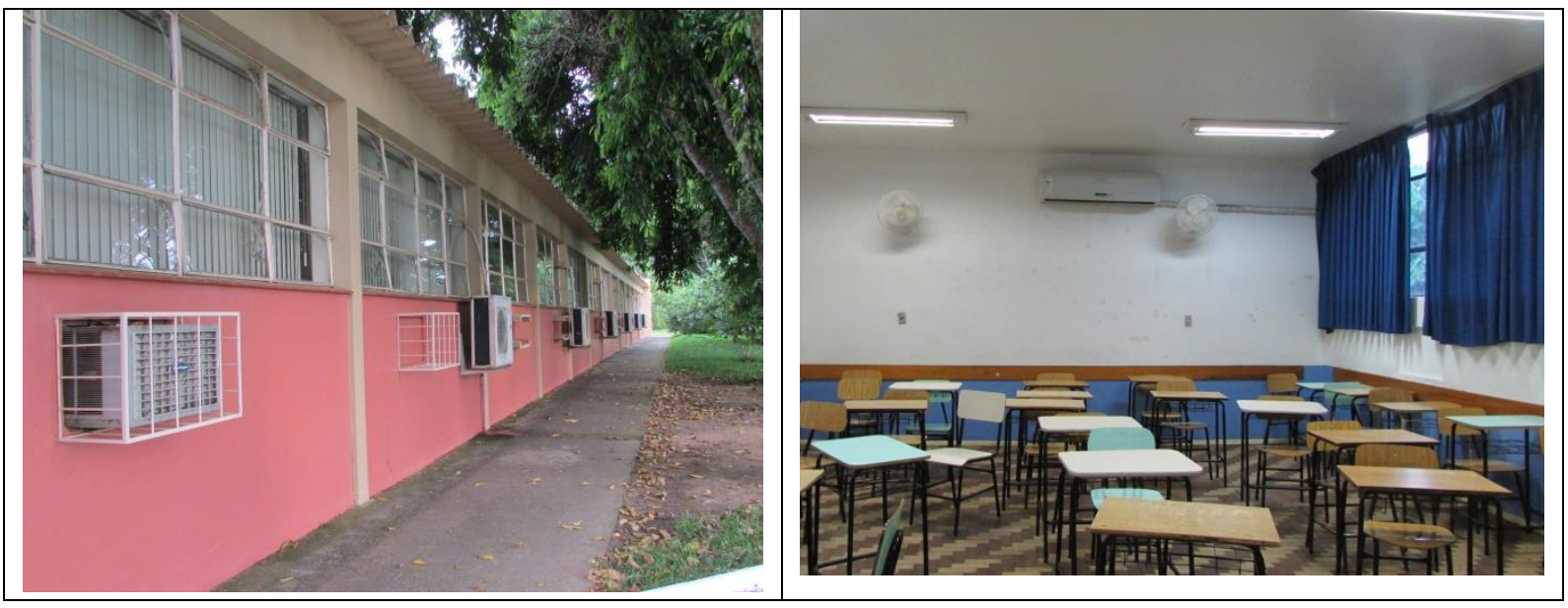

\section{Posição da edificação e a trajetória aparente do Sol}

A fachada Sul tem sua configuração opaca com panos de alvenaria e poucas partes com fechamento transparente. Esse tipo de configuração é bastante usual para edificações nessa posição geográfica, pois nesta situação a fachada Sul não recebe insolação em nenhum período do ano.

Considerando-se que todos os cômodos devem ter pelo menos uma janela, se ela estiver situada em uma parede voltada para o Sul, essa não se mostra como melhor 
posição, pois não recebe insolação direta. A insolação direta, fazendo com que os raios solares entrem no ambiente é interessante, pois higieniza o ambiente pela função fungicida do Sol, deixando o ambiente mais agradável, menos umido e sem cheiro de mofo.

Figura 17 - Fachadas voltadas para o Sul.

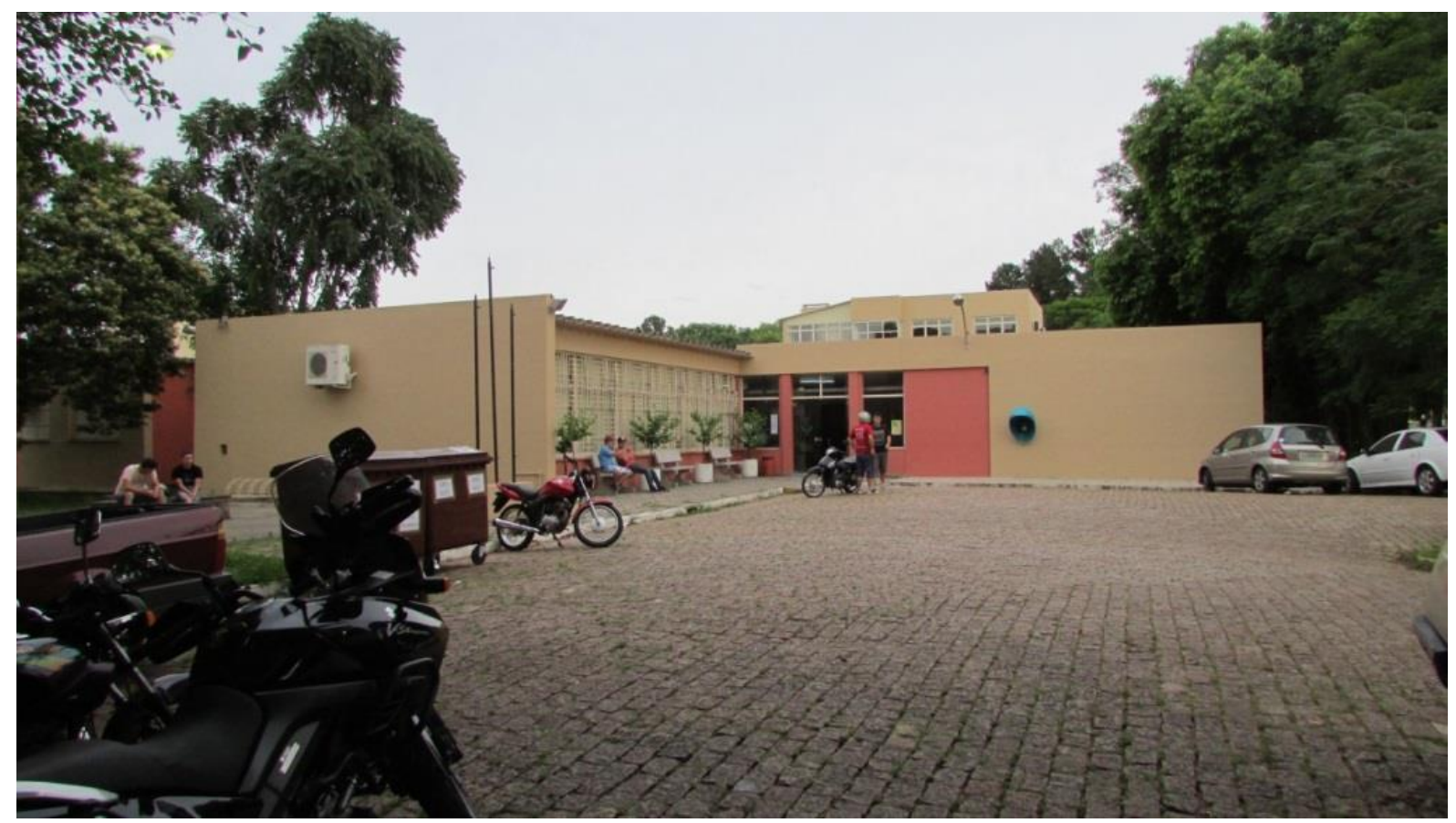

Voltada para a posição solar Leste, a fachada da figura 18 tem mais de $50 \%$ do seu fechamento em material transparente. Essa esta posição solar é bastante privilegiada pois recebe uma alta carga de insolação nas primeiras horas do dia, que é de pouca intensidade e faz a higienização do ambiente deixando o ambiente salubre e agradável para o uso.

Figura 18 - Fachadas voltadas para o Leste.
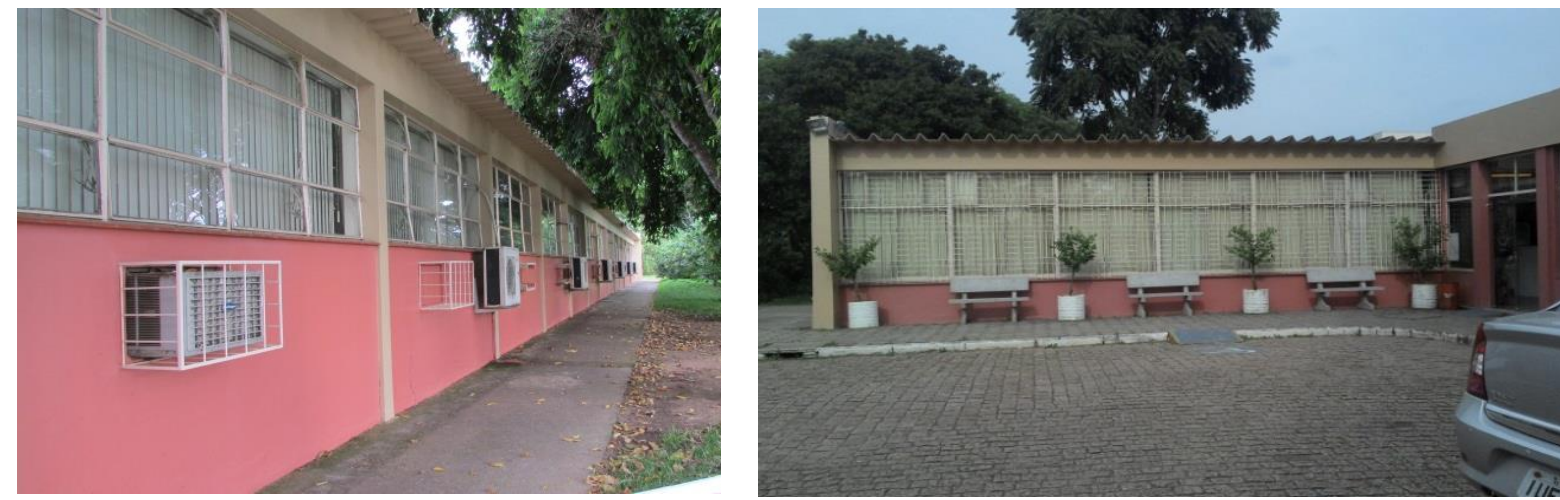
A fachada Norte é considerada a de melhor insolação para a latidude na qual se encontra a cidade de Santa Maria. Este posicionamento solar possibilita o controle da incidência dos raios solares nas diferentes estações. Durante o período de verão os raios solares incidem nessa região mais perpendiculares, não atingindo a fachada Norte. Nos período de inverno, pela inclinação do eixo da Terra, os raios solares incidem de maneira a penetrar nesta fachada o que é interessante, pois aquece o ambiente.

Sempre que possível deixa-se cômodos menos nobres voltados para o Oeste, quando isso não é possível deve-se proteger esta fachada contra os raios solares. Por receber uma insolação quase horizontal, o ideal é que a proteção seja feita com brises verticais ou com vegetação.

O projeto do Ctism não tira proveito dessa posição solar tendo poucas aberturas em suas fachadas voltadas para o Norte, como podemos observar na figura 19.

Figura 19 - Fachadas voltadas para o Norte.

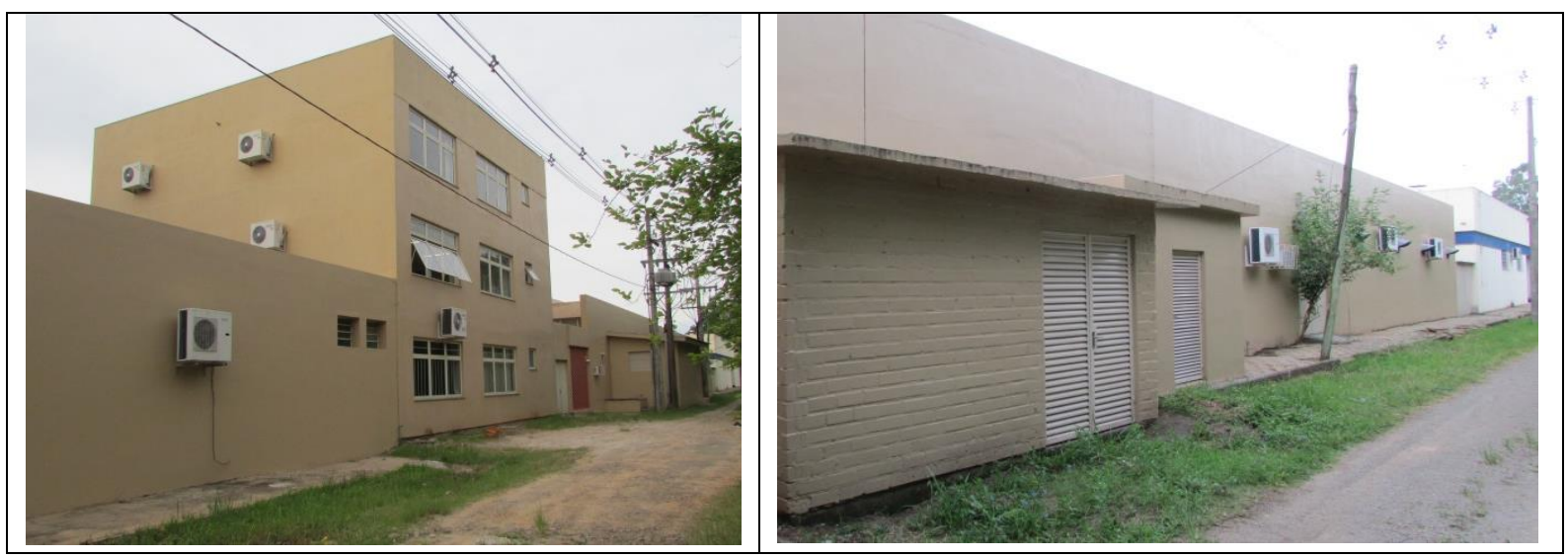

A fachada Oeste é, em boa parte, protegida pelo prédio da Imprensa Univessitária da UFSM. Essa é a posição solar que mais recebe carga térmica durante 0 ano, concentrada nas horas finais da tarde.

Figura 20 - Fachadas voltadas para o Oeste.

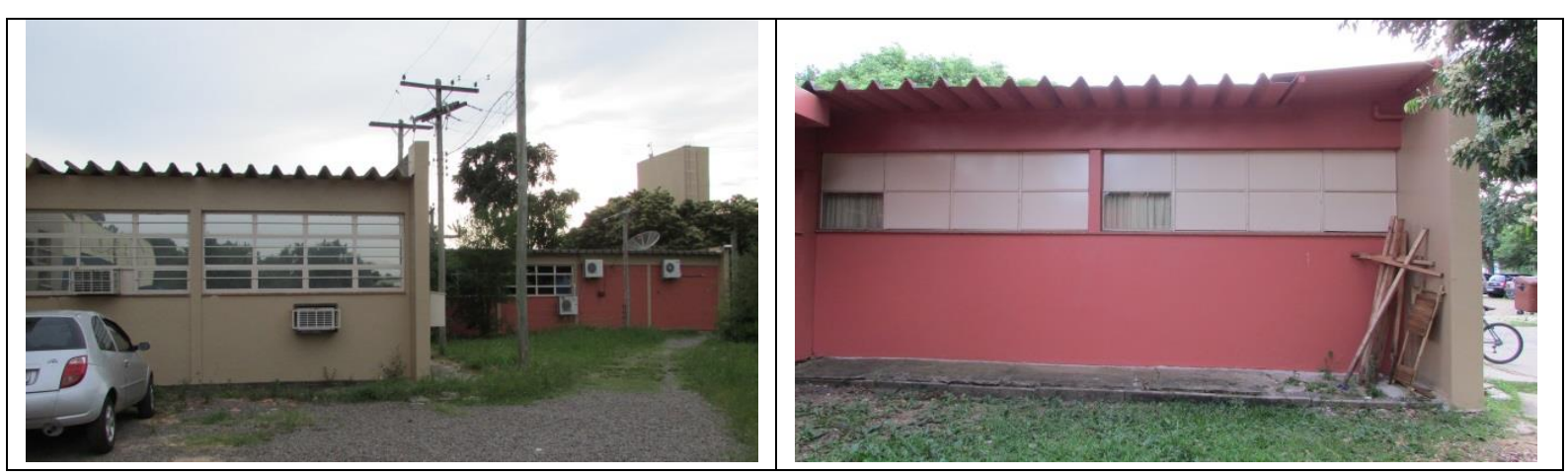


$\mathrm{Na}$ porção restante desta fachada observamos algumas janelas na Foto $4.10 \mathrm{com}$ a aplicação de películas espelhadas, e na Foto 4.11 vemos a pintura das janelas, o que comprova que este posicionamento solar é bastante crítico para a abertura de janelas.

\section{Configuração da planta baixa e as esquadrias}

As janelas altas, como mostra a Foto 4.12, sem que seja deixada uma viga na parte superior, são de grande valia na análise da questão térmica das edificações. $O$ fato de ter uma abertura junto ao teto permite que 0 ar quente saia totalmente por diferença de pressão, sem que fique armazenado um colchão de ar quente na parte superior do ambiente.

Figura 21 - Janelas voltadas para o corredor e para a área externa.
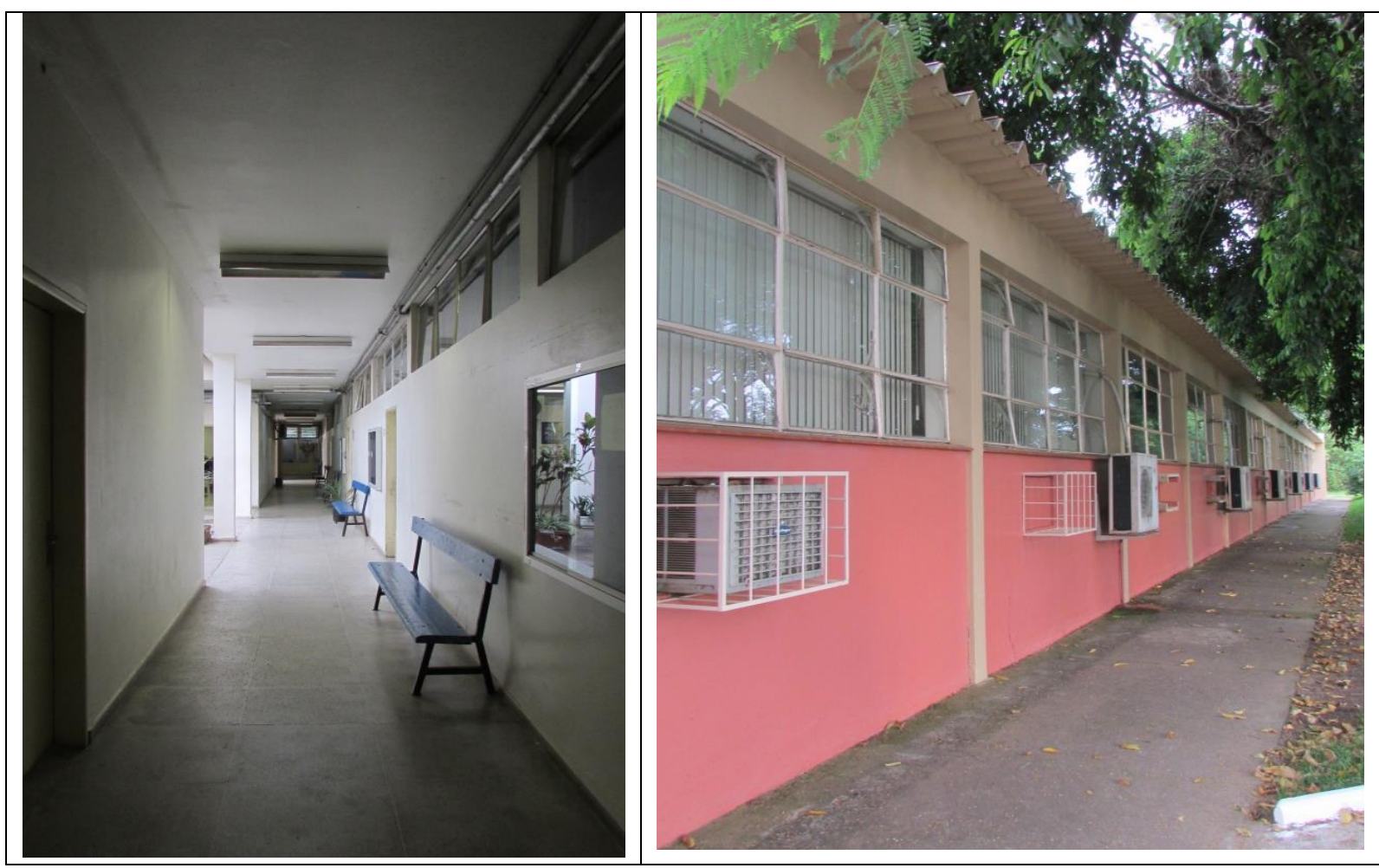

Além disso, essa configuração das janelas tem como vantagem a possibilidade de ventilação higiênica nos meses de frio, sem que para isso seja preciso que o vento passe na altura dos estudantes.

As janelas da outra extremidade, Foto 4.13 , da sala são maiores e abrem para o exterior do prédio. Estas têm sua abertura na base e na parte superior, o que permite a regulagem da ventilação. Se forem abertas apenas as janelas da parte superior, essa situação permite a ventilação higiênica como citado no parágrafo anterior. Se forem abertas as janelas inferiores, permite a ventilação cruzada pelo ambiente, passando na altura dos indivíduos, proporcionando conforto térmico nos períodos de calor. Essa ventilação é otimizada pela diferença de altura entre as duas esquadrias em lados opostos do ambiente, pois o ar quente, menos denso, tende a subir, encontrando uma 
abertura na parte superior, cria uma corrente ascendente para fora do ambiente. A figura 21 mostra a composição das janelas na parte interna das salas de aula.

Figura 22 - Configuração das salas de aula.

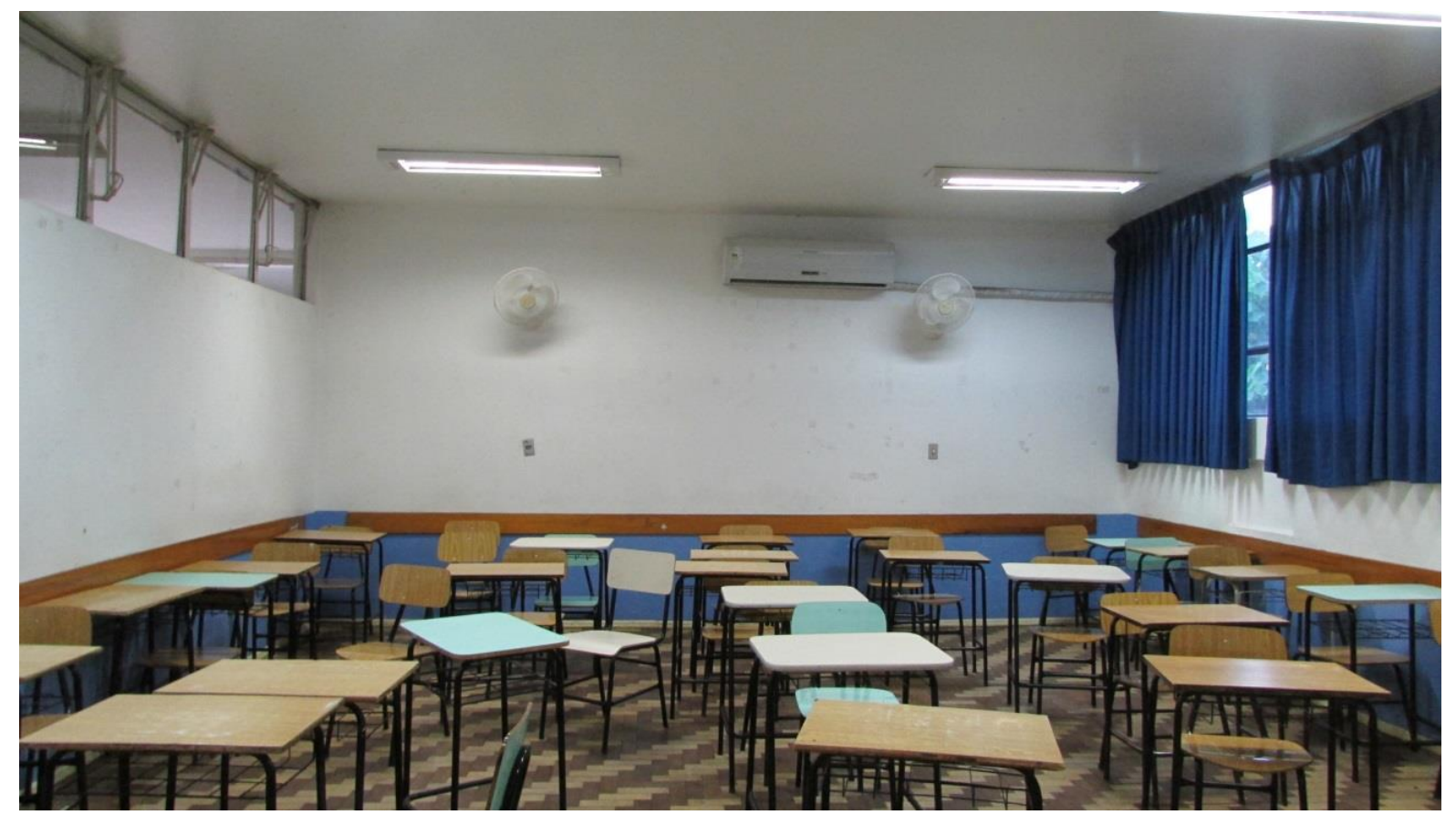

No corpo do edifício temos a presença de dois pátios a céu aberto, conforme a figura 22. Essa configuração é interessante, pois permite, além do aumento da ventilação, a entrada de luz natural, bem mais recomendada que a artificial, para ambientes escolares.

Figura 23 - Pátios internos a edificação.
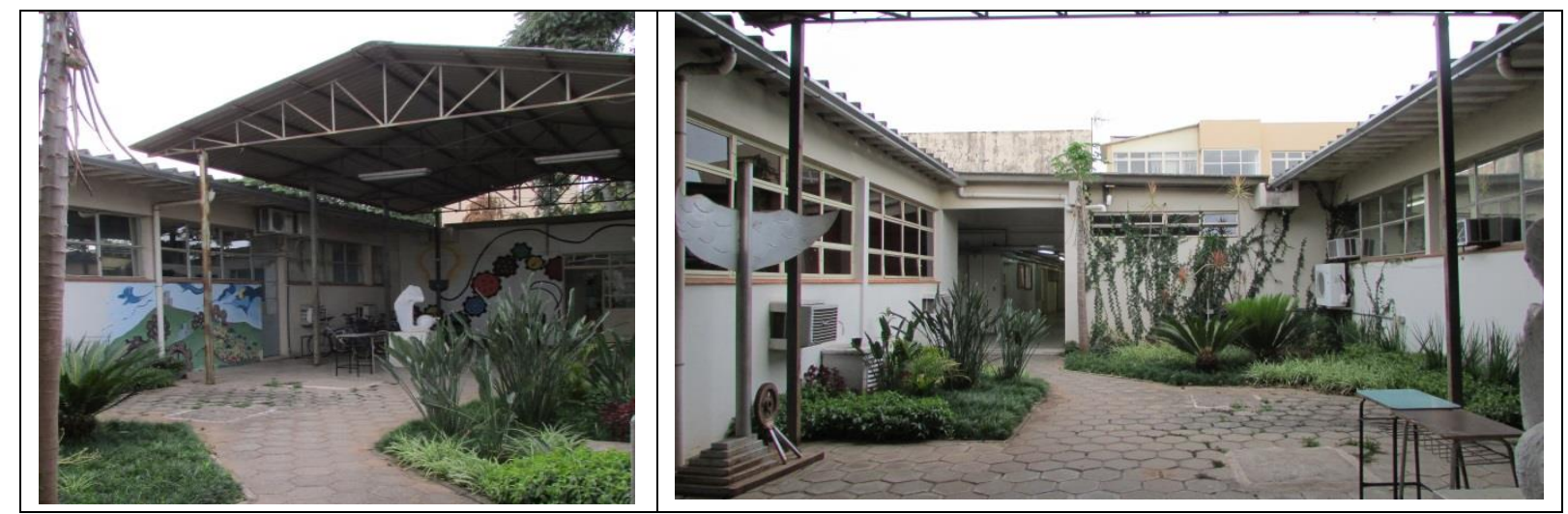

\section{Considerações finais}

O crescimento da demanda de energia elétrica no Brasil e no mundo se tornou motivo de preocupação, em especial pela necessidade do uso mais racional e eficiente da energia. Nossas habitações são apenas parte do nosso habitat, elas estão intimamente 
ligadas ao meio ambiente circundante, regional e global. É nossa responsabilidade adaptar nossas edificações para que possamos diminuir a poluição do meio ambiente. Assim, todos os esforços no sentido adaptar as edificações para que elas fiquem mais sustentáveis são louváveis pela preocupação com o planeta no qual vivemos.

Com algumas alterações e o uso correto dos elementos de condicionamento natural, seria possível diminuir o número de horas nas quais o condicionamento depende do uso dos aparelhos de condicionamento térmico artificial.

Assim, seguindo os parâmetros de conforto já identificados, as possíveis estratégias de melhoramento do conforto são: Sul;

a) adequar as esquadrias, utilizando aberturas de 25 a $40 \%$ das fachadas Norte e

b) evitar radiação solar direta nos interiores da edificação, posicionar as aberturas nas fachadas Norte e Sul permitindo ventilação ao nível dos corpos dos ocupantes;

c) utilizar coberturas leves e isolantes;

d) otimizar a ventilação em todos os ambientes criando em todas as salas estratégias de ventilação como já existe em algumas salas;

e) criar sistemas de aquecimento para essa edificação, ativo e passivo, sistemas de calefação;

f) trocar as esquadrias de baixa qualidade para diminuir as trocas de calor com o meio ambiente externo;

g) construir os novos blocos do Ctism alongados com suas fachadas maiores voltadas para Norte e Sul, a edificação atual está posicionada da maneira oposta.

h) utilizar aberturas de 25 a $40 \%$ das fachadas Norte e Sul, nas salas com mais de uma parede voltada para a área externa fazer a troca do posicionamento das janelas, modificado sua configuração;

i) proteger as esquadrias da fachada Oeste, para evitar a insolação direta dentro da edificação, isso pode ser feito por meio de brises;

j) pintar as paredes e cobertura em cores claras para diminuir a carga térmica absorvida nos períodos quentes.

Deve-se informar, para que haja um entendimento dos estudantes, professores e funcionários, sobre o funcionamento dessas estratégias de conforto, como que as esquadrias devem ser abertas nos momentos certos para que possam ventilar, as cortinas devem ser fechadas no momento de sol, no período de calor e abertas para que os raios solares possam incidir na parte interna da edificação, aquecendo o ambiente no inverno.

\section{Referências}

ABNT NBR 15220-3: Desempenho térmico de edificações - parte 3: Zoneamento bioclimático brasileiro e diretrizes construtivas para habitações unifamiliares de interesse social. Rio de Janeiro.

GIVONI, Baruch. Climate considerations in building and urban design. New York: Van Nostrand Reinhold, 1998.

LAMBERTS, Roberto; DUTRA, Luciano; PEREIRA, Fernando Oscar Ruttakay. Eficiência energética na arquitetura. São Paulo: PW, 1997. 
LENGEN, Johan Van. Manual do arquiteto descalço. São Paulo: Empório do Livro, 2008.

OLGYAY, Victor. Design with climate. Princeton: Princeton University Press, 1963.

TOLEDO, Eustaquio. Ventilação natural das edificações. Maceió: Edufal, 1999.

Madalena Russi é mestre em Engenharia Civil e Ambiental - Conforto Térmico pela Universidade Federal de Santa Maria, graduada em Arquitetura e Urbanismo e licenciada pelo Curso de Formação de Professores para a Educação Profissional e Tecnológica da Universidade Federal de Santa Maria.

Endereço: Avenida Itaimbé, 654 - 97050-330 - Santa Maria - Rio Grande do Sul Brasil.

E-mail:madalenarussi@gmail.com.

Karla Marques da Rocha é professora da Disciplina de Práticas de Investigação no Ensino no Curso de Formação de Professores para a Educação Profissional e Tecnológica da Universidade Federal de Santa Maria.

Endereço: Avenida Roraima, 1000 - prédio 16 - 97001-970 - Santa Maria - Rio Grande do Sul - Brasil.

E-mail: karlarocha@terra.com.br.

Recebido em 3 de maio de 2014.

Aceito em 27 de junho de 2014. 